\title{
Development of a flexible anode for lithium-ion batteries from electrospun carbon-magnetite composite microfibers
}

Desarrollo de un ánodo flexible para baterías ion-litio de microfibras compuestas de carbono-magnetita electrohiladas

\author{
Carlos A. Velásquez (D) ${ }^{1}$, Ferley A. Vásquez (D) ${ }^{*}$, Mónica Álvarez-Láinez (D)², Andrés F. Zapata-González \\ (iD) ${ }^{2}$, Jorge A. Calderón (iD) 1 \\ ${ }^{1}$ Centro de Investigación, Innovación y Desarrollo de Materiales - CIDEMAT, Universidad de Antioquia. Calle 70 \# 52 - 21. \\ C. P. 050010 . Medellín, Colombia. \\ ${ }^{2}$ Grupo de Investigación en Ingeniería de Diseño - Grid, Universidad EAFIT, Carrera 49 \# sur-50. C. P. 050022. Medellín, \\ Colombia.
}

\section{CITE THIS ARTICLE AS:}

C. A. Velásquez, F. A. Vásquez, M. Álvarez, A. F. Zapata and J.

A. Calderón. "Development of a flexible anode for lithium-ion batteries from electrospun carbon-magnetite composite microfibers", Revista Facultad de Ingeniería Universidad de Antioquia, no. 106, pp. 94-102, Jan-Mar 2023. [Online].

Available: https :

//www.doi.org/10.17533/

udea.redin. 20210319

\section{ARTICLE INFO:}

Received: September 15, 2020 Accepted: March 09, 2021

Available online: March 09, 2021

\section{KEYWORDS:}

Electrochemistry; energy conversión; composite material; carbon; iron

Electroquímica; conversión de energía; material compuesto; carbón; hierro
ABSTRACT: The development of a binder-free material is gaining ground as a flexible anode in lithium-ion batteries due to the higher specific capacity and possibilities of usage in portable appliances. In this work, magnetite nanoparticles $\left(\mathrm{Fe}_{3} \mathrm{O}_{4}\right.$-NPs) were incorporated into carbon microfibers (CMFs) by electrospinning technique to improve the specific capacity of active material, retaining the high flexibility of the CMFs. The composite active material ( $\mathrm{CMFs}-\mathrm{Fe}_{3} \mathrm{O}_{4}$ ) was characterized by Raman spectroscopy, Thermogravimetric analyses (TGA), and transmission electron microscopy (TEM) to determine the composition, structure, and morphology of the composite. Electrochemical tests were done to evaluate the performance of the composite material as an anode in lithium-ion batteries. $\mathrm{Fe}_{3} \mathrm{O}_{4}$-NPs with particle sizes from 30 to $40 \mathrm{~nm}$ were incorporated into CMFs $(800 \mathrm{~nm})$, and the TEM images showed a homogeneous distribution of $\mathrm{Fe}_{3} \mathrm{O}_{4}$-NPs. The electrochemical tests evidenced that magnetite incorporation increases the specific capacity by $42 \%$ on the first cycle and $20 \%$ on the $50^{t} h$ cycle. Similarly, the Coulombic efficiency increases by $20 \%$ in the composite material.

RESUMEN: El desarrollo de material libre de aglutinantes está ganando terreno como ánodo flexible en las baterías de iones de litio debido a la mayor capacidad específica y a las posibilidades de uso en aparatos portátiles. En este trabajo, las nanopartículas de magnetita ( $\mathrm{Fe}_{3} \mathrm{O}_{4}$-NPs) se incorporaron a microfibras de carbono (CMFs) mediante la técnica de electrohilado para mejorar la densidad energética del material activo conservando la alta flexibilidad de las CMFs. El material activo compuesto (CMFs- $\mathrm{Fe}_{3} \mathrm{O}_{4}$ ) se caracterizó por espectroscopía Raman, análisis termogravimétricos (TGA) y microscopía electrónica de transmisión (TEM) para determinar la composición, estructura y morfología del compuesto. Se realizaron pruebas electroquímicas para evaluar el desempeño del material compuesto como ánodo en baterías de iones de litio. Se incorporaron $\mathrm{Fe}_{3} \mathrm{O}_{4}-\mathrm{NP}$ con un tamaño de partícula de 30-40 nm en CNF (800 $\mathrm{nm}$ ) y las imágenes TEM mostraron una distribución homogénea de $\mathrm{Fe}_{3} \mathrm{O}_{4}-\mathrm{NP}$. Las pruebas electroquímicas evidenciaron que la incorporación de magnetita aumenta la capacidad específica en un $42 \%$ en el primer ciclo y en un $20 \%$ en el ciclo 50 . De la misma forma, la eficiencia coulómbica aumenta un $20 \%$ en el material compuesto.

\section{Introduction}

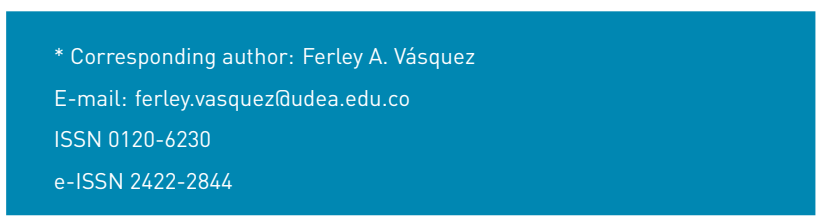

Currently, lithium-ion batteries (LiB) have been gaining importance as an energy storage device in electronic apparatus, renewable energies, and electric vehicles, due to their high energy density and long cycle life [1]. The most used active materials for the anode in LiB are graphite bases, whose materials have a specific 
capacity between $300-400 \mathrm{mAh} g^{-1}$ [2]. Nowadays, several studies are conducted to improve the specific capacity and cycle life of anodic materials. Therefore, carbonaceous nanostructured materials with transition metal oxides incorporation have been developed, obtaining specific capacities from $700 \mathrm{mAh} g^{-1}$ to $800 \mathrm{mAh} g^{-1}$ [3]. Magnetite $\left(\mathrm{Fe}_{3} \mathrm{O}_{4}\right)$ is one of the most promissory oxides incorporated into carbonaceous materials due to the high theoretical capacity (926 mAh $\left.g^{-1}\right)$, easier synthesis, and low cost. Additionally, magnetite can be synthesized by sol-gel, hydrothermal processes, or electrochemical methods [4, 5]. However, poor electronic conductivity restricts the electrochemical performance of magnetite $\left(\mathrm{Fe}_{3} \mathrm{O}_{4}\right)$ as pure active material in LiB. For this reason, carbon- $\mathrm{Fe}_{3} \mathrm{O}_{4}$ composite materials have been developed and outstanding discharge capacities (until $1200 \mathrm{mAh} \mathrm{g}^{-1}$ ) have been achieved $[6,7]$.

Carbon microfibers (CMFs) can be obtained through pyrolysis processes of some raw materials such as wood, oil derivates, and polymers [8]. The pyrolysis of polyacrylonitrile (PAN) microfibers obtained by electrospinning synthesis provides better properties due to the high control of CMFs morphology [9]. The electronic conductivity of the carbonaceous material depends on the graphitization degree, and it is proportional to the thermal treatment temperature, obtaining an adequate graphitization degree at $900^{\circ} \mathrm{C}$ under an inert atmosphere [10]. However, some transition metal oxides incorporated in the CMFs, such as iron oxides, are unstable at this temperature. For that reason, the CMFs with $\mathrm{Fe}_{3} \mathrm{O}_{4}$-NPS must be thermally treated at low temperatures as $700^{\circ}$ $\mathrm{C}$, in order to obtain the $\mathrm{Fe}_{3} \mathrm{O}_{4}-\mathrm{NPs}$ without phase transition in the $\mathrm{Fe}_{3} \mathrm{O}_{4}$.

This work reported the development of carbon-magnetite composite microfibers (CMFs- $\mathrm{Fe}_{3} \mathrm{O}_{4}$ ) by the electrospinning technique, as a flexible anode for lithium-ion batteries. The composite material was achieved by incorporating $\mathrm{Fe}_{3} \mathrm{O}_{4}-\mathrm{NPs}$ during the electrospinning process of PAN precursor, followed by the thermal treatment at $700^{\circ} \mathrm{C}$ to promote the CMFs graphitization without magnetite phase transitions. The electrochemical performance of CMFs- $\mathrm{Fe}_{3} \mathrm{O}_{4}$ composite was tested as anode material in lithium-ion batteries.

\section{Experimental section}

\subsection{Material synthesis}

$\mathrm{Fe}_{3} \mathrm{O}_{4}-\mathrm{NPs}$ were synthesized by electrochemical oxidation of a low-carbon steel bar in the electrolyte of $0.1 \mathrm{M} \mathrm{NaCl}$ dissolved in ethanol:water $11: 1)$ solution, as described by T. Marín et al. [11]. Pristine CMFs were synthesized by the electrospinning technique at 9
$\mathrm{kV}$, using polyacrylonitrile (PAN) as a precursor, with a gap between needle-tip and the collector of $12 \mathrm{~cm}$ [12]. The pyrolysis of microfibers was done at $900{ }^{\circ} \mathrm{C}$ for $1 \mathrm{~h}$ under nitrogen atmosphere to obtain CMFs with a high graphitization degree. The CMFs- $\mathrm{Fe}_{3} \mathrm{O}_{4}$ composite was obtained by dispersion of $2 \%$ of $\mathrm{Fe}_{3} \mathrm{O}_{4}-\mathrm{NPs}$ in the polymeric solution used for electrospinning procedure. Once the polyacrylonitrile (PAN) microfibers were obtained, the pyrolysis of this precursor was done at $700^{\circ} \mathrm{C}$.

\subsection{Characterization}

The anodic materials were characterized by Raman spectroscopy to determine the graphitization degree and the $\mathrm{Fe}_{3} \mathrm{O}_{4}$ incorporation; the spectra were taken in a Horiba Jobin Yvon (Labram HR) Nikon (BX41) microscope, with a CCD detector (1024×256 pixels), and the software Lab Spec5. The amount of $\mathrm{Fe}_{3} \mathrm{O}_{4}-\mathrm{NPs}$ incorporated into CMFs was determined by Thermogravimetric analysis (TGA). TGA profiles were obtained in a TA Instruments model Q500 device, heating from $25^{\circ} \mathrm{C}$ to $900{ }^{\circ} \mathrm{C}$ under air atmosphere, with a scan rate of $10{ }^{\circ} \mathrm{C} \mathrm{min}^{-1}$. The morphology, microfiber size, and $\mathrm{Fe}_{3} \mathrm{O}_{4}-\mathrm{NPs}$ distribution were analyzed by transmission electron microscopy (TEM) in a Tecnai G2 F20 FEI equipment, operated by the software Gatan ${ }$. The specific surface area of CMFs was calculated according to the $\mathrm{N}_{2}$ adsorption isotherms at $-197.2{ }^{\circ} \mathrm{C}$ (ASAP2020, Micrometrics, U.S.) using the Barrett-Emmett-Teller (BET) Equation and volume and pore size analysis using the Barrett-Joyner-Halenda (BJH) model. Prior to measurement, $50 \mathrm{mg}$ of sample were outgassed at $280^{\circ} \mathrm{C}$ under nitrogen flow at 10-2 Torr for $15 \mathrm{~h}$. The Modulus of elasticity and ultimate tensile strength were evaluated in the microfiber textile after thermal treatment using the universal mechanical testing system Instrom 3366.

\subsection{Electrochemical characterization}

Half-cells were assembled in "T-cells", using disks of $12 \mathrm{~mm}$ diameter of CMFs and CMFs- $\mathrm{Fe}_{3} \mathrm{O}_{4}$ on current collectors of copper without binder addition as working electrodes. Lithium foils were used as a counter and reference electrodes. Glass microfiber discs (Whatman GF/D) were used as separators. The electrolyte was prepared using $1 \mathrm{M} \mathrm{LiF}$ P dissolved in ethylene carbonate (EC) and dimethyl carbonate (DMC) with a weight ratio of $11: 1)$. Additionally, the half-cells were assembled in a MBraun glovebox under an argon atmosphere with $\mathrm{O}_{2}$ and moisture concentrations lower than $1 \mathrm{ppm}$. The open-circuit potential (OCP) of assembled half cells was checked before the electrochemical measurements, and they were set between $2.8 \mathrm{~V}$ and $3.0 \mathrm{~V}$ vs. $\mathrm{Li} / L i^{+}$. The electrochemical test was performed in Autolab PGSTAT 302 potentiostat, Gamry 600 Potentiostat, and Solartron 
1470E multichannel system. The discharge capacity and cycled life were determined by cycling tests at $0.3 \mathrm{C}\left(0.1 \mathrm{~A} \mathrm{~g}^{-1}\right)$ in the potential windows of $0.01 \mathrm{~V}$ to $3.0 \mathrm{~V}$ vs. $\mathrm{Li} / \mathrm{Li}^{+}$. The conductivity and lithium-ion diffusivity in the anodic material at different states of charge (SOC) $\left(0.01,1.5\right.$, and $3.0 \mathrm{~V}$ vs. $\mathrm{Li} / \mathrm{Li}^{+}$) were determined by electrochemical impedance spectroscopy (EIS) measurements, using a sinusoidal amplitude of 10 $\mathrm{mV}$. The reversibility of oxide-reduction processes in the potential range from $0.01 \mathrm{~V}$ to $3.0 \mathrm{~V}$ vs. $\mathrm{Li} / L i^{+}$was determined by cyclic voltammetry (CV) curves, using scan rates of $0.1,1.0$, and $2.0 \mathrm{mVs}^{-1}$. The rate capability tests were done at $\mathrm{C}$-rates of $0.1,0.2,0.5,1,2,5$, and $10 \mathrm{C}$.

\section{Results and discussion}

\subsection{Material characterization}

The presence and quantity of NPs $\mathrm{Fe}_{3} \mathrm{O}_{4}$ incorporated into the CMFs after thermal treatment of pyrolysis were determined by Raman spectroscopy and TGA, as shown in Figure 1. Raman characterization was also carried out to the polyacrylonitrile (PAN) precursor before and after the pyrolysis process to observe the presence of the magnetite nanoparticles and identify that magnetite structure was retained after the pyrolysis. The Raman spectrum shows a band at $667 \mathrm{~cm}^{-1}$ correlated with vibration mode $\mathrm{A} 1 \mathrm{~g}$ of magnetite phase $\left(\mathrm{Fe}_{3} \mathrm{O}_{4}\right)$ [13]. After the thermal treatment, the CMFs with and without $\mathrm{Fe}_{3} \mathrm{O}_{4}$ incorporation show two bands at 1350 and 1520 $\mathrm{cm}^{-1}$ associated with amorphous carbon (D) and graphitic carbon (G) of CMFs, respectively [8, 10, 14-16]. The $D$-band derives from a disorder in the $s p^{2}$ - hybridized carbon, while the $\mathrm{G}$-band is related to the tangential stretching $\left(E_{2 g}\right)$ mode of graphite. The presence of magnetite was evidenced in the CMFs- $\mathrm{Fe}_{3} \mathrm{O}_{4}$ material; the electrospinning process and the graphitization heat treatment do not induce appreciable changes in the structure of magnetite. The graphitization degree can be calculated by $D / G$ bands intensity ratio, incrementing graphitization degree as $D / G$ value decreases. A higher $D / G$ ratio (> 1) suggests that carbon is mainly amorphous and a $D / G$ ratio lower than unity suggests that the carbon is mainly graphitic [10]. The $D / G$ ratio for the CMFs and CMFs- $\mathrm{Fe}_{3} \mathrm{O}_{4}$ materials are 1.04 and 1.13, respectively. The values approximately equal to the unity indicate an adequate graphitization degree of CMFs with and without $\mathrm{Fe}_{3} \mathrm{O}_{4} \mathrm{NPs}$, and an intermediate electronic conductivity could be expected. The slight reduction of $D / G$ ratio for CMFs- $\mathrm{Fe}_{3} \mathrm{O}_{4}$ could be associated with the lower thermal treatment temperature $\left(700^{\circ} \mathrm{C}\right)$ compared with that for CMFs $\left(900^{\circ} \mathrm{C}\right)$. At this point, it is important to remember that the lower thermal treatment temperature applied for CMFs- $\mathrm{Fe}_{3} \mathrm{O}_{4}$ samples was chosen in order to avoid a structural transformation of magnetite. A high thermal treatment temperature could increase the graphitization degree; nevertheless, some phase transitions in magnetite could take place at temperatures superior to $700^{\circ} \mathrm{C}[10]$. Consequently, a reduction in the electronic conductivity of CMFs- $\mathrm{Fe}_{3} \mathrm{O}_{4}$ material is expected, because of the lower grade of graphitization of the carbonaceous material and by the presence of magnetite $[10,17,18]$.

TGA analysis was done under air atmosphere to calculate the magnetite amount in the active material. Figure $1 \mathrm{~b}$ shows the TGA of CMFs with and without $\mathrm{Fe}_{3} \mathrm{O}_{4}-\mathrm{NPs}$ under an oxidizing atmosphere. The weight loss observed at $100{ }^{\circ} \mathrm{C}$ corresponds to the water releasing in the active materials, which is $5.5 \%$ and $10.3 \%$, for the CMFs and CMFs- $\mathrm{Fe}_{3} \mathrm{O}_{4}$ materials, respectively. The subsequent weight loss around $530{ }^{\circ} \mathrm{C}$ and $560{ }^{\circ} \mathrm{C}$ for CMFs and CMFs- $\mathrm{Fe}_{3} \mathrm{O}_{4}$ respectively, corresponds to carbon oxidation [19]. For CMFs above $560^{\circ} \mathrm{C}$ complete weight loss takes place. For the CMFs $-\mathrm{Fe}_{3} \mathrm{O}_{4}$ active material above $530{ }^{\circ} \mathrm{C}$, a residual weight of $5.03 \%$ is obtained, due to the $\mathrm{Fe}_{3} \mathrm{O}_{4}$ NPs incorporated in the CMFs. The high specific surface area in CMFs was obtained with a BET (Brunauer-Emmett-Teller) area of $188.98 \mathrm{~m}^{2} \mathrm{~g}^{-1}$ and nanoporous of $3.13 \mathrm{~nm}$.

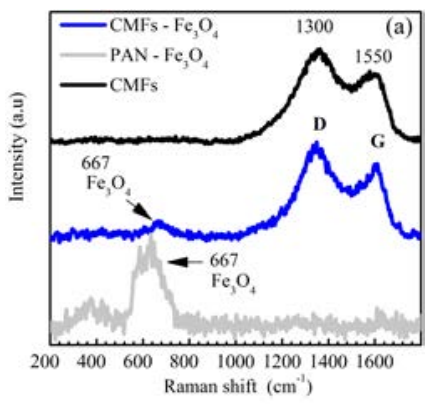

(a)

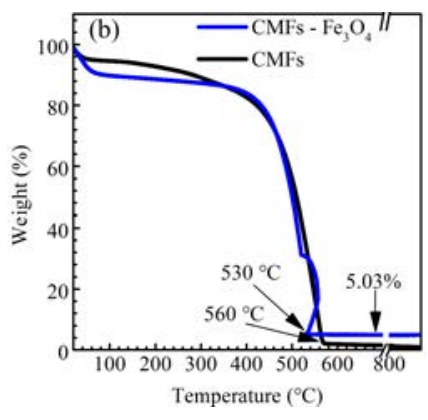

(b)
Figure 1 (a) Raman spectroscopy of CMFs with and without $\mathrm{Fe}_{3} \mathrm{O}_{4}$-NPs incorporated, and PAN- $\mathrm{Fe}_{3} \mathrm{O}_{4}$ precursor. (b) TGA in air atmosphere of CMFs with and without $\mathrm{Fe}_{3} \mathrm{O}_{4}-\mathrm{NPs}$

Figure 2 shows TEM images of CMFs- $\mathrm{Fe}_{3} \mathrm{O}_{4}$ active material. Microwires with approximately $800 \mathrm{~nm}$ of diameter are observed. Nanoparticles between 30-40 $\mathrm{nm}$ are observed through the cross-section of CMFs. TEM images corroborate the incorporation of $\mathrm{Fe}_{3} \mathrm{O}_{4} \mathrm{NPs}$ into CMFs, indicating the success of the electrospinning method in the synthesis of the composite active material. EDX analysis on dark regions of CMFs- $\mathrm{Fe}_{3} \mathrm{O}_{4}$ shows $17.08 \% \mathrm{w} / \mathrm{w}$ of iron, which could be due to the clusters of magnetite nanoparticles. According to the results of the mechanical testing of the material, the CMFs exhibited a modulus of elasticity of $2.64 \pm 0.22 \mathrm{GPa}$ and ultimate tensile strength of $18.03 \pm 0.77 \mathrm{MPa}$. The mechanical properties of CMFs are similar to flexible materials as 
nylon ( $E=2-4 \mathrm{GPa}$ and $\sigma_{u}=45-90 \mathrm{MPa}$ ) [20]. In the same way, the visual aspect of the CMFs- $\mathrm{Fe}_{3} \mathrm{O}_{4}$ anode in Figure 2c shows a flexible textile, in which no binder is required to assembly the half cell.

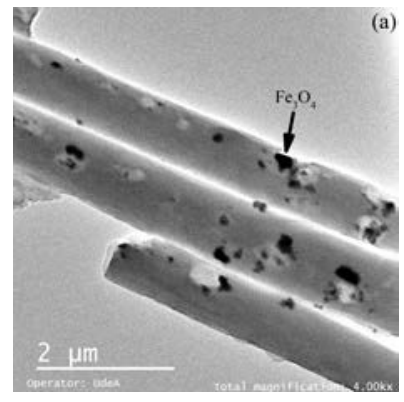

(a)
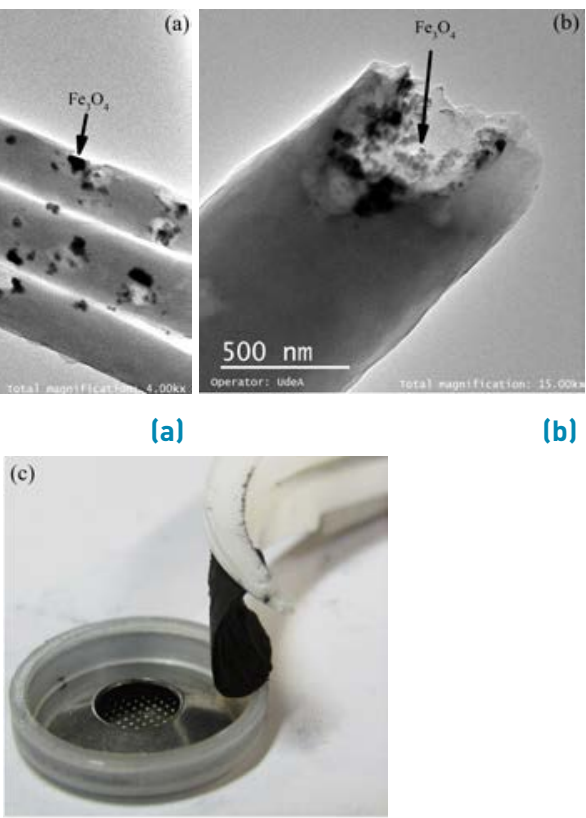

(c)

Figure 2 (a, b) TEM images of CMFs- $\mathrm{Fe}_{3} \mathrm{O}_{4}$ material after thermal treatment. (c) Visual aspect of the CMFs- $\mathrm{Fe}_{3} \mathrm{O}_{4}$ flexible anode

The CMFs with and without $\mathrm{Fe}_{3} \mathrm{O}_{4}$ incorporation samples were assembled in half cells. They then were evaluated by the cycling test at $0.3 \mathrm{C}\left(0.1 \mathrm{Ag}^{-1}\right)$ in the potential range of 0.01 to $0.03 \mathrm{~V}$ vs. $\mathrm{Li} / \mathrm{Li}^{+}$in order to determine the specific capacity, cycle life and Coulombic efficiency (C.E). Figure 3a shows the charge-discharge profile of the second and third cycles. The specific capacities during discharge (delithiation) for CMFs and CMFs- $\mathrm{Fe}_{3} \mathrm{O}_{4}$ samples were 335 and $617 \mathrm{mAh} g^{-1}$, respectively. The discharge capacity for CMFs was higher than the theoretical capacity of graphite [21,22]. Capacity values reported for carbonaceous materials are commonly between 300 and $400 m \mathrm{Ahg}^{-1}[14,23,24]$. However, the incorporation of $\mathrm{Fe}_{3} \mathrm{O}_{4}-\mathrm{NPs}$ into the CMFs increases the discharge capacity up $617 \mathrm{mAh} g^{-1}$. This value is similar to CMFs with high $\mathrm{Fe}_{3} \mathrm{O}_{4}$ incorporation (32 - 49\%) reported in previous works $\left(522-762 \mathrm{mAh} g^{-1}\right)[3,7]$. The high specific capacities obtained in CMFs- $\mathrm{Fe}_{3} \mathrm{O}_{4}$ active material suggest that not only the intercalation process takes place during the lithiation process, but an additional process like double-layer capacitance and conversion reactions in $\mathrm{Fe}_{3} \mathrm{O}_{4}$-NPs could occur, improving the

\subsection{Electrochemical characterization}

capacity of the anode. It is well known that the theoretical capacity of the magnetite during the conversion process is $928 \mathrm{mAh} g^{-1}$ [5]. The discharge capacity higher than theoretical capacity has been associated with the superior amount of active sites and side reaction in the interphases iron oxides-carbon [6].

Charge profiles (lithiation) shown in Figure 3a exhibit a change in the slope at potentials between 1-2 V vs. $\mathrm{Li} / \mathrm{Li}^{+}$, associated with the lithiation process in the $\mathrm{Fe}_{3} \mathrm{O}_{4}$ phase. Figure 3b presents the cycle life of the active materials at $0.3 \mathrm{C}\left(0.1 \mathrm{~A} \mathrm{~g}^{-1}\right)$. The CMFs- $\mathrm{Fe}_{3} \mathrm{O}_{4}$ material shows a higher fading of the capacity than the CMFs during the cycling. However, after 50 cycles, the specific capacity was still higher for the CMFs- $\mathrm{Fe}_{3} \mathrm{O}_{4}$ active material than for the CMFs. The incorporation of magnetite in the CMFs increases the initial capacity a $42 \%$, and after 50 cycles, the discharge capacity is $20 \%$ higher than CMFs. The Coulombic efficiencies of active materials are shown in Figure 3c. The CMFs- $\mathrm{Fe}_{3} \mathrm{O}_{4}$ exhibited a Coulombic efficiency of $90 \%$, while the Coulombic efficiency for CMFs was $73 \%$. Such Coulombic efficiencies were retained by both active materials after 50 cycles. Clearly, there is a superior capacity recovery of carbonaceous material with magnetite during charge-discharge cycles compared to carbonaceous material without magnetite. These results indicate that the incorporation of $\mathrm{Fe}_{3} \mathrm{O}_{4}$-NPs into CMFs improves the electrochemical properties of the CMFs obtained by the electrospinning process.
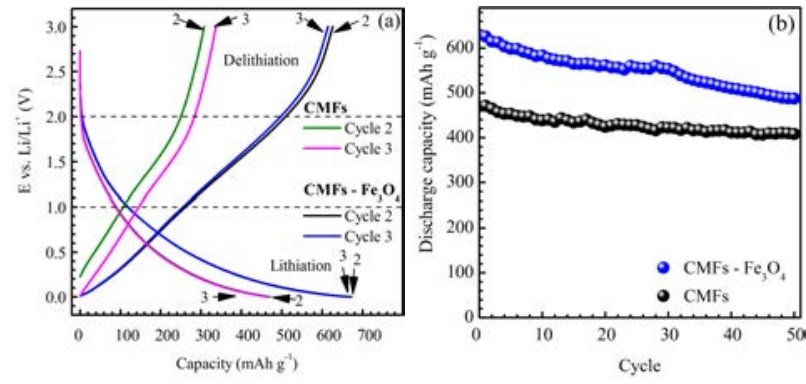

(a)

(b)

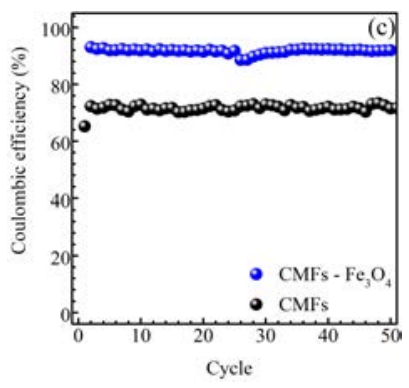

(c)

Figure 3 (a) Charge- discharge profile of CMFs and CMFs- $\mathrm{Fe}_{3} \mathrm{O}_{4}$ active materials a $0.3 \mathrm{C}$ (b) Cycle life of active materials at $0.3 \mathrm{C}$. (c) Coulombic efficiency 


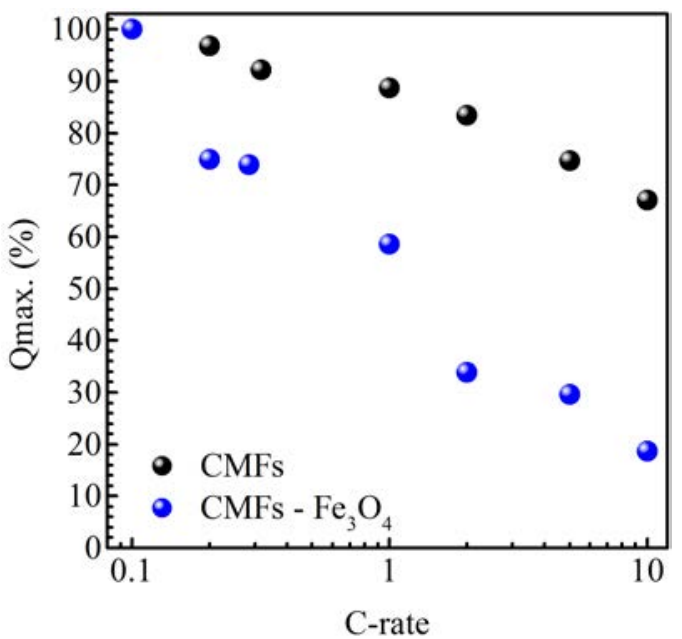

Figure 4 Discharge capacity retention under several C-rates for the CMFs and $\mathrm{CNF}-\mathrm{Fe}_{3} \mathrm{O}_{4}$, charge at $0.3 \mathrm{C}\left(0.1 \mathrm{~A} g^{-1}\right)$

The Discharge process was performed under different current densities to evaluate the capacity retention at several C-rates, as shown in Figure 4. The charge process was always carried out at $\mathrm{C}$-rate of $0.3 \mathrm{C}\left(0.1 \mathrm{~A}^{-1}\right)$, while the discharge was done at $0.1,0.2,0.5,1,2,5$, and $10 \mathrm{C}$. Lower capacity retention at $\mathrm{C}$-rates higher than $0.2 \mathrm{C}$ was observed in CMFs- $\mathrm{Fe}_{3} \mathrm{O}_{4}$ with respect to those exhibited for CMFs. The CMFs- $\mathrm{Fe}_{3} \mathrm{O}_{4}$ active material retains only $15 \%$ of capacity at $10 \mathrm{C}$, which is lower than that of CMFs $(66 \%)$. The low-capacity retention of CMFs- $\mathrm{Fe}_{3} \mathrm{O}_{4}$ could be due to a lower electronic conductivity of that material with respect to the pure CMFs and the changes in the energy storing mechanisms. This hypothesis can be supported by two fundamental factors. Firstly, the reduction of graphitization degree of $\mathrm{CNF}-\mathrm{Fe}_{3} \mathrm{O}_{4}$ due to the lower temperature of the pyrolysis process, which was $200{ }^{\circ} \mathrm{C}$ below than that of pure CMFs. As a result, a higher $\mathrm{D} / \mathrm{G}$ ratio (low graphitization grade) of $\mathrm{CMFs}-\mathrm{Fe}_{3} \mathrm{O}_{4}$ was obtained [10]. Secondly, because magnetite has lower intrinsic electronic conductivity compared with CMFs, the incorporation of $\mathrm{Fe}_{3} \mathrm{O}_{4}$ can reduce the conductivity of the composite material [25].

The energy storing mechanisms, oxidation-reduction processes, and reversibility of the anodic materials were evaluated by cyclic voltammetry (CV) tests. CV tests were performed at several scan rates in the potential range between $0.01-3.0 \mathrm{~V}$ vs $\mathrm{Li}_{\mathrm{L}} \mathrm{Li}^{+}$. Figure 5 shows the voltammograms for both active materials. CV curves indicate that the materials behave like capacitors. Such behavior has been reported for carbonaceous materials with a high surface area [26-28]. The CMFs show an electric double-layer capacitor shape, and a linear increment of the current with the scan rate denoting that storing energy is mainly produced by the double-layer capacitance. The CMFs with magnetite show lower

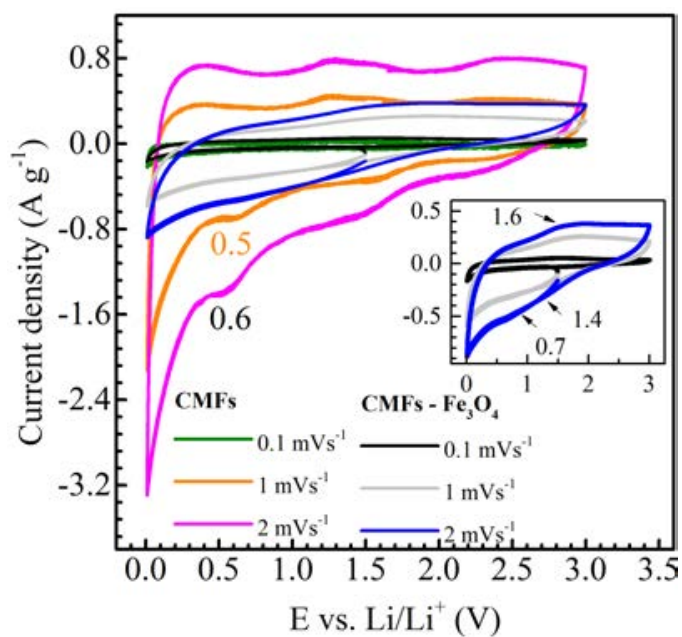

Figure $\mathbf{5}$ Cyclic voltammetry at several scan rates of CMFs with and without $\mathrm{Fe}_{3} \mathrm{O}_{4}$

linearity, whose effect could be due to the combined storing energy contributions of double-layer capacitance, intercalation, and faradic process [12]. The double-layer storing energy mechanism of CMFs explains the superior capacity retention at high c-rates. Small cathodic current peaks are observed in the $\mathrm{CV}$ curves of the materials. For instance, pure CMFs sample exhibited a cathodic peak at potentials of $0.5-0.6 \mathrm{~V}$ vs $L i / L i^{+}$, which is associated with the formation of the solid electrolyte interface (SEI). The CMFs $-\mathrm{Fe}_{3} \mathrm{O}_{4}$ material exhibited two cathodic current peaks between $0.7 \mathrm{~V}$ and $1.4 \mathrm{~V}$ vs. $L i / L i^{+}$and at $1.6 \mathrm{~V}$ vs. $\mathrm{Li} / \mathrm{Li}^{+}$, which are associated with reduction processes of magnetite, as described by reactions (1) and (2) [7].

$$
\begin{aligned}
& \mathrm{Fe}_{3} \mathrm{O}_{4}+2 \mathrm{Li}^{+}+2 e^{-} \rightarrow L i_{2} \mathrm{Fe}_{3} \mathrm{O}_{4} \quad \mathrm{E}=1.2 \mathrm{~V} \\
& L i_{2} \mathrm{Fe}_{3} \mathrm{O}_{4}+6 \mathrm{Li}^{+}+6 e^{-} \rightarrow 3 \mathrm{Fe}^{0}+4 L i_{2} \mathrm{O} \quad \mathrm{E}=0.6 \mathrm{~V}
\end{aligned}
$$

The small anodic peak observed at $1.6 \mathrm{~V}$ vs. $\mathrm{Li} / \mathrm{Li}^{+}$ in the CMFs- $\mathrm{Fe}_{3} \mathrm{O}_{4}$ sample is due to the iron oxidation in the magnetite, from $\mathrm{Fe}^{0}$ to $\mathrm{Fe}^{2+}$ and $\mathrm{Fe}^{3+}$, as described by reaction (3) [7].

$3 \mathrm{Fe}^{0}+4 \mathrm{Li}_{2} \mathrm{O}-8 e^{-} \rightarrow \mathrm{Fe}_{3} \mathrm{O}_{4}+8 \mathrm{Li} \quad \mathrm{E}=1.6 \mathrm{~V}$

The oxide/reduction processes observed more clearly in the $\mathrm{CV}$ curves of the $\mathrm{CMFs}-\mathrm{Fe}_{3} \mathrm{O}_{4}$ material performed at high scan rates indicate that the superior capacity of this material is due to the combination of several charge/discharge processes, like lithium intercalation in graphitic carbon, capacitive storage in the amorphous carbon fraction, and conversion reaction in the $\mathrm{Fe}_{3} \mathrm{O}_{4}$-NPs [29], confirming such said during the analysis of the cycling test. Electrochemical impedance spectroscopy (EIS) tests at different potentials, and numbers of cycles were conducted in order to 
determine the parameters that control the kinetics of the electrochemical performance of CMFs and CMFs- $\mathrm{Fe}_{3} \mathrm{O}_{4}$ active materials during charge-discharge and the degradation processes during cycling. Figure 6 shows the Nyquist diagrams of the EIS curves for CMFs and CMFs- $\mathrm{Fe}_{3} \mathrm{O}_{4}$ after 25 cycles at $1.5 \mathrm{~V}$ vs. $\mathrm{Li} / \mathrm{Li}^{+}$. Three capacitive loops in the high to medium frequency regions and a linear behavior at low frequencies are observed. The first loop at high frequency lapproximately $12 \mathrm{kHz}$ is attributed to the capacitance in parallel combination with the resistance of the passive layer (SEI) during the interaction between the active material and the electrolyte. The second capacitive loop at intermediate frequencies $(100-500 \mathrm{~Hz})$ is associated with the double-layer capacitance $\left(C_{1}\right)$ in parallel with the charge transfer resistance $\left(R_{1}\right)$ of the graphitic phase of the CMFs. The third capacitive loop at intermediate frequencies is associated with the charge transfer resistance in parallel with the double-layer capacitance of the $\mathrm{Fe}_{3} \mathrm{O}_{4}$ phase for the CMFs- $\mathrm{Fe}_{3} \mathrm{O}_{4}$, active material and with capacitive processes in the non-graphitic phase for the active material CMFs. Additionally, the energy stored by the double-layer capacitance is more significant in the CMFs, as was evidenced in the voltammogram, which can cause the time constant for this process was not coupled with other processes. In the CMFs- $\mathrm{Fe}_{3} \mathrm{O}_{4}$ material in all potentials and in the CMFs polarized at 3.0V, the capacitive loops at intermediate frequencies were coupled. The linear region at low frequencies $(0.01 \mathrm{~Hz})$ is associated with diffusion processes of $\mathrm{Li}^{+}$in the active material.

The CMFs impedance values are slightly lower than for the CMFs- $\mathrm{Fe}_{3} \mathrm{O}_{4}$ material, which suggests that the incorporation of magnetite and the lower graphitization degree of the CMFs- $\mathrm{Fe}_{3} \mathrm{O}_{4}$ reduce the electronic conductivity of the active material [30]. The resistance of capacitive loops increases at high potentials of polarization, i.e., 1.5 and $3.0 \mathrm{~V}$ vs. $L i / L i^{+}$, which is consistent with the decrease in the electronic conductivity of the material when $\mathrm{Li}^{+}$ions are removed. However, the slope of the linear region at low frequencies as can be seen in the CMFs (Figure 6a) at low potential (0.01V vs. $\mathrm{Li} / \mathrm{Li}^{+}$) increased with respect to the potentials of $1.5 \mathrm{~V}$ $3 \mathrm{~V}$ vs. $\mathrm{Li} / \mathrm{Li}^{+}$, which indicates that a high potential, the $\mathrm{Li}^{+}$mobility is lower, due to the reduction of vacancies in the structures.

Electrical parameters calculated with the equivalent electrical circuit fit (inserted in Figure 6) of the EIS experimental results are presented in Table 1. The impedance of a simple faradic reaction can be calculated in terms of a CPE as described by Equation (1) [31].

$$
Z_{\phi}(\omega)=R s e+\frac{R s e}{1+(j \omega)^{\alpha} Y^{*} R p}
$$

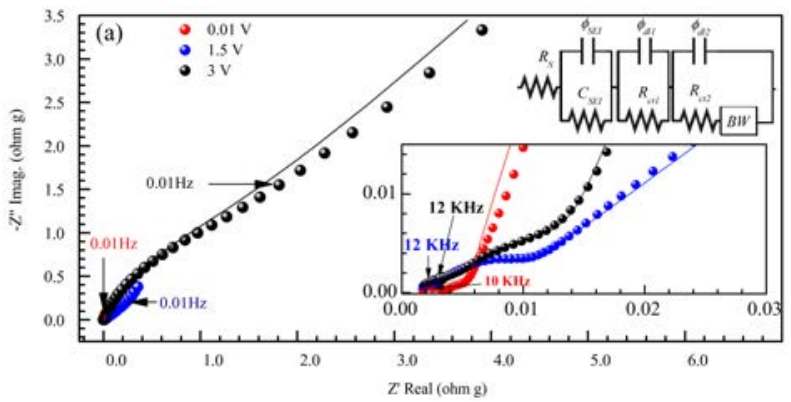

(a)

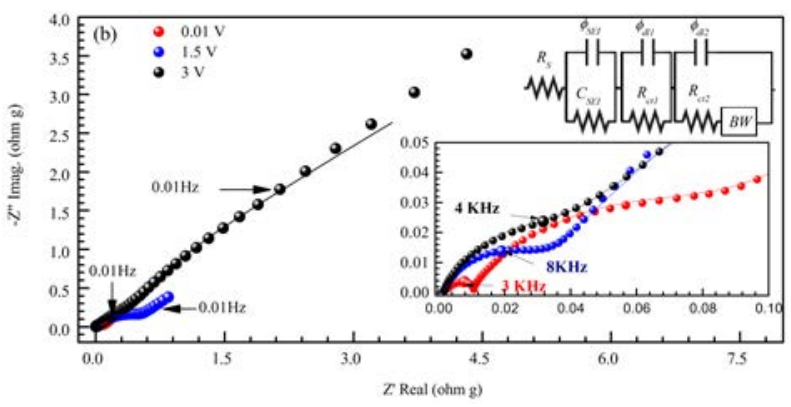

(b)

Figure 6 Nyquist diagram of active materials after 25 cycles. (a) $\mathrm{CMFs}$ (b) CMFs- $\mathrm{Fe}_{3} \mathrm{O}_{4}$

Where, $\omega$ is the frequency, $R_{s e}$ y $R_{p}$ are the series and parallel resistances, respectively. " $\alpha$ " and " $Y$ " are the exponential factor and the pseudocapacitance of the CPE $(\phi)$ element, respectively.

The Effective capacitance of the SEl was calculated as described by Equation (2), and the effective capacitance of the double layer is calculated as described by Equation (3) [31].

$$
\begin{aligned}
& \text { Cef.SEI }=Y^{\frac{1}{\alpha}} R_{S E I}^{(1-\alpha) / \alpha} \\
& \operatorname{Cef}_{\cdot 1,2}=\left[Y\left(\frac{1}{R_{s e}}+\frac{1}{R_{p}}\right)^{(\alpha-1)}\right]^{1 / \alpha}
\end{aligned}
$$

Where, $R_{S E I}$ is the SEl resistance, $Y$ is the pseudocapacitance, " $\alpha$ " is the exponential factor of pseudocapacitor, Rse and Rp are the series and parallel resistances with the pseudocapacitor, respectively [32]. The SEI resistance $\left(R_{S E I}\right)$ of the CMFs active material shows a high stability at several potentials, and it does not present major changes with the SOC level. On the other hand, in the CMFs- $\mathrm{Fe}_{3} \mathrm{O}_{4}$ active material, higher resistance and more significant changes of resistances at potentials from $0.01 \mathrm{~V}$ to $1.5 \mathrm{~V}$ vs. $\mathrm{Li} / \mathrm{Li}^{+}$are observed, confirming the lower electronic conductivity of this material with respect to that observed for $C M F_{s}$. In addition, these results show the effect of magnetite addition on the SEl formation and the variation of SEI resistance, which could be associated with conversion processes that take place in the magnetite phase during 
cycling.

The diffusivity of $L i^{+}$ions is calculated using the Equation $D=L / B W^{2}$, where " $L$ " is the half distance of diffusion, which corresponds to the average microfiber radius 1400 $\mathrm{nm}$ ) and " $B W$ " is the characteristic time root square of the diffusive element. The diffusivity constant $(D)$ calculated from EIS results shows, in general terms, higher values for the material without magnetite compared to the material with magnetite incorporated. These results are consistent with the superior capacity retention at high discharge speeds observed in the pure $C M F_{s}$. The lower ion mobility in CMFs- $\mathrm{Fe}_{3} \mathrm{O}_{4}$ limits the discharge capacity at high $\mathrm{C}$-rates. Both active materials exhibit a $\mathrm{Li}^{+}$ diffusivity similar to values reported in previous works $\left(10^{-12} \mathrm{~cm}^{2} \mathrm{~s}^{-1}\right)[21,22]$. The higher Rct $_{2}$ values for the CMFs- $\mathrm{Fe}_{3} \mathrm{O}_{4}$ active material could be associated with the lower electronic conductivity of the magnetite phase, explaining the low charge capacity retention at discharge rates $>0.2 \mathrm{C}$, as evidenced in Figure 4. The capacitance of the $C e f_{1}$ and $C e f_{2}$ shows higher values for CMFs without magnetite, which could be due to superior energy stored by the double-layer capacitance in carbon microfibers as shown in the double-layer capacitor shape of the cyclic voltammetry in Figure 5. In the same way, the lower time constants $T_{1}$ and $T_{2}$ in the pure CMFs than in the CMFs- $\mathrm{Fe}_{3} \mathrm{O}_{4}$ denote that a lower time is required for energy storing in the double-layer capacitance.

Figure 7 shows the Nyquist diagram for the CMFs- $\mathrm{Fe}_{3} \mathrm{O}_{4}$ active material at potentials of $1.5 \mathrm{~V}$ vs. $\mathrm{Li} / \mathrm{Li}^{+}$at a different number of cycles. The Nyquist diagrams show three capacitive loops at high and intermediate frequencies and a linear region at low frequencies, as previously described in Figure 6. The resistances and characteristic times of the different processes that take place in the material were calculated by the analysis of the Distribution of Relaxation Times (DRT), as described by Schmidt et al. (see Figure 7) [33]. Each peak present in Figure 7 is associated with the characteristic time of the processes involved lithiation and delithiation processes. Figure $7 \mathrm{~b}$ shows greater changes in time constants between cycles 15 and 30; after cycle 30, no significant changes in time constants take place.

The characteristic times and resistance calculated by DRT analysis of EIS in Figure 7 are shown in Table 2. The $R_{S E I}$ stabilizes for cycles 45 and 60 . The $R c t_{1}$ associated with the resistance of carbonous phase (CMFs) is lower than the resistance of the internal phase $\left(\mathrm{Fe}_{3} \mathrm{O}_{4}\right) \mathrm{Rct}_{2}$, which is consistent with the lower electronic conductivity observed in previous analysis in the CMFs- $\mathrm{Fe}_{3} \mathrm{O}_{4}$ active material. The Resistances $R c t_{1}$ and $R c t_{2}$ decrease with the number of cycles. Diffusion times increase slightly with the number of cycles, obtaining a constant value after 30 cycles.
Table 1 Electrical parameters calculated of Nyquist diagrams fit in Figure 6

\begin{tabular}{|c|c|c|c|}
\hline Parameter & Potential (V) & CMFs & CMFs- $\mathrm{Fe}_{3} \mathrm{O}_{4}$ \\
\hline \multirow{3}{*}{ Rs lohm g) } & 0.01 & $2.12 \times 10^{-03}$ & $1.44 \times 10^{-03}$ \\
\hline & 1.5 & $1.67 \times 10^{-03}$ & $1.67 \times 10^{-03}$ \\
\hline & 3 & $2.07 \times 10^{-03}$ & $1.64 \times 10^{-03}$ \\
\hline \multirow{3}{*}{ Cef SEI $\left(\mu F g^{-1}\right)$} & 0.01 & $2.06 \times 10^{+04}$ & $2.95 \times 10^{+03}$ \\
\hline & 1.5 & $1.42 \times 10^{+03}$ & $6.53 \times 10^{+03}$ \\
\hline & 3 & $1.50 \times 10^{+03}$ & $7.86 \times 10^{+03}$ \\
\hline \multirow{3}{*}{ Rs lohm g) } & 0.01 & $3.02 \times 10^{-03}$ & $9.49 \times 10^{-03}$ \\
\hline & 1.5 & $3.02 \times 10^{-03}$ & $29.80 \times 10^{-03}$ \\
\hline & 3 & $3.73 \times 10^{-03}$ & $27.10 \times 10^{-03}$ \\
\hline \multirow{3}{*}{$S E I$ (s) } & 0.01 & $62.20 \times 10^{-06}$ & $28.00 \times 10^{-06}$ \\
\hline & 1.5 & $4.31 \times 10^{-06}$ & $195.0 \times 10^{-06}$ \\
\hline & 3 & $5.61 \times 10^{-06}$ & $213.0 \times 10^{-06}$ \\
\hline \multirow{3}{*}{ Rct $_{1}$ lohm g ) } & 0.01 & $4.13 \times 10^{-03}$ & $15.70 \times 10^{-03}$ \\
\hline & 1.5 & $9.43 \times 10^{-03}$ & $678.0 \times 10^{-03}$ \\
\hline & 3 & $21.10 \times 10^{-03}$ & $37.20^{x}-03$ \\
\hline \multirow{3}{*}{$C e f_{1}\left(\mu F g^{-1}\right)$} & 0.01 & $1.51 \times 10^{+07}$ & $2.79 \times 10^{+06}$ \\
\hline & 1.5 & $1.30 \times 10^{+04}$ & $1.10 \times 10^{+05}$ \\
\hline & 3 & $1.44 \times 10^{+04}$ & $1.06 \times 10^{+04}$ \\
\hline \multirow{3}{*}{$T_{1}(\mathrm{~s})$} & 0.01 & $6.24 \times 10^{-02}$ & $4.40 \times 10^{-02}$ \\
\hline & 1.5 & $1.23 \times 10^{-04}$ & $7.44 \times 10^{-02}$ \\
\hline & 3 & $3.04 \times 10-04$ & $3.93 \times 10^{-04}$ \\
\hline \multirow{3}{*}{$R_{c} t_{2}$ lohm g ) } & 0.01 & $20.80 \times 10^{-05}$ & $6.58 \times 10^{-02}$ \\
\hline & 1.5 & 2.29 & 1.42 \\
\hline & 3 & 2.25 & 1.75 \\
\hline \multirow{3}{*}{$T_{2}$ (s) } & 0.01 & $2.75 \times 10^{-02}$ & $3.48 \times 10^{-01}$ \\
\hline & 1.5 & $9.73 \times 10^{-01}$ & $5.10 \times 10^{+01}$ \\
\hline & 3 & $4.30 \times 10^{-01}$ & $2.11 \times 10^{-03}$ \\
\hline \multirow{3}{*}{$C e f_{2}\left(\mu F g^{-1}\right)$} & 0.01 & $1.32 \times 10^{+08}$ & $5.28 \times 10^{+06}$ \\
\hline & 1.5 & $4.26 \times 10^{+05}$ & $8.32 \times 10^{+07}$ \\
\hline & 3 & $1.92 \times 10^{+05}$ & $1.21 \times 10^{+03}$ \\
\hline \multirow{3}{*}{$W\left(S s^{1 / 2} g^{-1}\right)$} & 0.01 & $4.90 \times 10^{-04}$ & $3.99 \times 10-02$ \\
\hline & 1.5 & $2.82 \times 10^{-01}$ & $1.92 \times 10^{-11}$ \\
\hline & 3 & $5.76 \times 10^{-04}$ & $1.61 \times 10^{-04}$ \\
\hline \multirow{3}{*}{$B W\left(s^{1 / 2}\right)$} & 0.01 & $1.08 \times 10^{-02}$ & 22.19 \\
\hline & 1.5 & $1.81 \times 10^{-02}$ & 4 \\
\hline & 3 & 2.99 & 1.2 \\
\hline \multirow{3}{*}{ Diffusivity $\left(\mathrm{cm}^{2} \mathrm{~s}^{-1}\right)$} & 0.01 & $1.37 \times 10^{-5}$ & $3.25 \times 10^{-12}$ \\
\hline & 1.5 & $4.88 \times 10^{-06}$ & $1.00 \times 10^{-10}$ \\
\hline & 3 & $1.79 \times 10^{-10}$ & $1.11 \times 10^{-09}$ \\
\hline
\end{tabular}

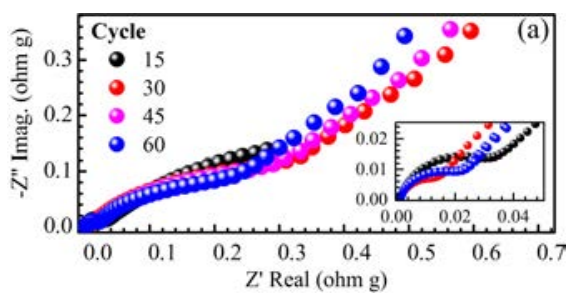

(a)

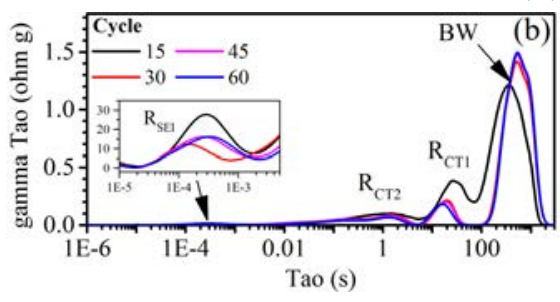

(b)

Figure 7 (a) Nyquist Diagram of CMFs- $\mathrm{Fe}_{3} \mathrm{O}_{4}$ active material at several numbers of cycles. (b) DRT analysis of EIS at several numbers of cycles 
Table 2 Resistances and characteristic times calculated by DRT analysis of EIS at $1.5 \mathrm{~V}$ vs. $\mathrm{Li} / \mathrm{Li}^{+}$, at a different number of cycles for $\mathrm{CMFs}-\mathrm{Fe}_{3} \mathrm{O}_{4}$

\begin{tabular}{lllll}
\hline Parameter & Cycle & & & \\
\hline & $\mathbf{1 5}$ & $\mathbf{3 0}$ & $\mathbf{4 5}$ & $\mathbf{6 0}$ \\
$R_{S E I}$ lohm g) & $3.03 \times 10^{-05}$ & $1.10 \times 10^{-05}$ & $1.92 \times 10^{-05}$ & $1.89 \times 10^{-05}$ \\
$T_{S E I}$ (s) & $2.88 \times 10^{-04}$ & $1.42 \times 10^{-04}$ & $2.54 \times 10^{-04}$ & $3.32 \times 10^{-04}$ \\
$R c t_{1}$ lohm g) & $3.54 \times 10^{-04}$ & $2.85 \times 10^{-04}$ & $2.55 \times 10^{-04}$ & $2.05 \times 10^{-04}$ \\
$T_{1}$ (s) & 1.47 & 1.50 & 1.45 & 1.29 \\
$R c t_{2}$ lohm g) & 0.60 & 0.23 & 0.22 & 0.19 \\
$T_{2}$ (s) & $2.68 \times 10^{+01}$ & $1.97 \times 10^{+01}$ & $1.90 \times 10^{+01}$ & $1.63 \times 10^{+01}$ \\
$R_{D}$ lohm g) & $2.11 \times 10^{-03}$ & $2.06 \times 10^{-03}$ & $2.10 \times 10^{-03}$ & $2.13 \times 10^{-03}$ \\
$T_{D}$ (s) & $3.68 \times 10^{+02}$ & $5.39 \times 10^{+02}$ & $5.39 \times 10^{+02}$ & $5.39 \times 10^{+02}$ \\
\hline
\end{tabular}

The reduction of charge transfer resistance with cycling could be due to the formation of a secondary phase as metallic iron $\left(F e^{0}\right)$, as described in reaction 2 . The diffusion time increases with the number of cycles, which could be due to the degradation of the active material during cycling.

\section{Conclusions}

Magnetite nanoparticles were successful incorporated into carbon microfibers by the electrospinning method and evaluated as binder- free anode material for lithium batteries. The electrochemical tests showed superior charge capacity of the CMFs- $\mathrm{Fe}_{3} \mathrm{O}_{4}$ composite $1617 \mathrm{mAh}$ $g^{-1}$ ) with respect to that exhibited for pure CFNs (335 $\mathrm{mAh} g^{-1}$ ). This effect was associated with the conversion processes that take place in the $\mathrm{Fe}_{3} \mathrm{O}_{4}$ phase and the superior amount of active sites for electrochemical reactions in the active material. Additionally, the $\mathrm{CMFs}-\mathrm{Fe}_{3} \mathrm{O}_{4}$ material presented a higher Coulombic efficiency than CMFs, obtaining values around $90 \%$. The rate capability was affected by the electronic conductivity of CMFs- $\mathrm{Fe}_{3} \mathrm{O}_{4}$, changes in the storing energy mechanisms, the incorporation of magnetite, and the lower graphitization degree obtained in CMFs during the pyrolysis process, inducing a lower discharge capacity retention at high cycling rates $(>0.2 \mathrm{C})$.

\section{Declaration of competing interest}

We declare that we have no significant competing interests, including financial or non-financial, professional, or personal interests interfering with the full and objective presentation of the work described in this manuscript.

\section{Acknowledgments}

The authors thank Colombian Ministry of Science, Technology and Innovation "Minciencias" for their financial support through the project 1115-745-58653.

\section{Funding}

This work was supported by Colombian Ministry of Science, Technology and Innovation "Minciencias" under the project 1115-745-58653, contract number FP44842-13-2017.

\section{Author contributions}

Conceptualization, supervision and funding acquisition, Mónica Álvarez-Láinez, and Jorge. A. Calderón; investigation, Carlos A. Velásquez, Ferley A. Vásquez, Andrés F. Zapata-González; writing-original draft preparation, Carlos A. Velásquez, Ferley A. Vásquez, Mónica Álvarez-Láinez, and Jorge. A. Calderón; writing-review and editing, all authors. All authors have read and agreed to the published version of the manuscript.

\section{Data availability statement}

The Raman spectrum is taken in Horiba Jobin Yvon (Labram HR) Nikon (BX41) microscope, the TGA is taken in TA Instruments model Q500 device, the TEM imajes are taken in Tecnai G2 F20 FEl equipment, the surface area is taken in ASAP2020, Micrometrics, U.S, the Modulus of elasticity and ultimate tensile is taken in Instrom 3366 aparatus, the DC electrochemical measures are taken in Autolab PGSTAT 302 potentiostat and Solartron 1470E multichannel system, and the AC electrochemical measures are taken in Gamry 600 Potentiostat. All equipments are periodically calibrated.

\section{References}

[1] L. Grajales, F. Arroyave, J. Thomas, and J. Gutiérrez, "Evaluation of the effect of the synthesis method on the performance of manganese 
spinel as cathode material in lithium-ion batteries," revista Facultad de Ingeniería Universidad de Antioquia, vol. 87, Apr. 2018. [Online]. Available: https://doi.org/10.17533/udea.redin.n87a06

[2] C. Julien, A. Mauger, A. Vijh, and K. Zaghib, Lithium Batteries. New York: Springer, 2016.

[3] L. Guo and et al., "Flexible $\mathrm{fe}_{3} \mathrm{O}_{4}$ nanoparticles/n-doped carbon nanofibers hybrid film as binder-free anode materials for lithium-ion batteries," Applied Surface Science, vol. 459, nov. 2018. [Online]. Available: https://doi.org/10.1016/j.apsusc.2018.08.001

[4] C. H. Wu and et al., "Performance improvement of lithium ion batteries using magnetite-graphene nanocomposite anode materials synthesized by a microwave-assisted method," Microelectronic Engineering, vol. 138, Apr. 2015. [Online]. Available: https://doi.org/10.1016/j.mee.2015.01.022

[5] Y. T. et al., "The fabrication of hollow magnetite microspheres with a nearly 100batteries," Chinese Chemical Letters, vol. 27, no. 6, Jun. 2016. [Online]. Available: https://doi.org/10.1016/j.cclet.2016.02.003

[6] Y. C. et al., " $\gamma$-fe2o3 nanoparticles aligned in porous carbon nanofibers towards long life-span lithium ion batteries," Electrochimica Acta, vol. 289, nov. 2018. [Online]. Available: https://doi.org/10.1016/j.electacta.2018.08.088

[7] Q. W. et al., "Synthesis of flexible fe304/c nanofibers with buffering volume expansion performance and their application in lithium-ion batteries," Journal of Power Sources, vol. 359, Aug. 2017. [Online]. Available: https://doi.org/10.1016/j.jpowsour.2017.05.020

[8] T. Wang and S. Kumar, "Electrospinning of polyacrylonitrile nanofibers," Applied Polymer Science, vol. 102, no. 2, Oct. 15. [Online]. Available: https://doi.org/10.1002/app.24123

[9] A. Mateus and S. Daza, "Producción de nanofibras poliméricas mediante el proceso de electrospinning y su uso potencial," Revista Mutis, vol. 8, no. 1, 2018. [Online]. Available: https: //doi.org/10.21789/22561498.1375

[10] O. F. et al., "Carbons from biomass precursors as anode materials for lithium ion batteries: New insights into carbonization and graphitization behavior and into their correlation to electrochemical performance," Carbon, vol. 128, Mar. 2018. [Online]. Available: https://doi.org/10.1016/j.carbon.2017.11.065

[11] T. Marín, D. Ortega, P. Montoya, and O. A. . J. Calderón, "A new contribution to the study of the electrosynthesis of magnetic nanoparticles: the influence of the supporting electrolyte," J Appl Electrochem, vol. 44, 2014. [Online]. Available: https: //doi.org/10.1007/s10800-014-0766-z

[12] A. Zapata, J. Cano, and M. Álvarez, "Driving commerce to the web-corporate intranets and the internet: Lines blur," $A d v$. Mater. Lett., vol. 10, no. 8, Feb. 15 2019. [Online]. Available: https://doi.org/10.5185/amlett.2019.9902

[13] I. Martínez, C. Gutiérrez, C. Argánis, and A. Vilchis, "Reduction of maghemite to magnetite over 304ss, in the presence of silver nanoparticles," Surface and Coatings Technology, vol. 324, Sep. 2017. [Online]. Available: https://doi.org/10.1016/j.surfcoat.2017.05.079

[14] T. L. et al., "Porous carbon nanofiber derived from a waste biomass as anode material in lithium-ion batteries," Journal of the Taiwan Institute of Chemical Engineers, vol. 95, Feb. 2019. [Online]. Available: https://doi.org/10.1016/j.jtice.2018.07.005

[15] L. J. et al., "a- $\mathrm{Fe}_{2} \mathrm{O}_{3}$ nanoparticle-loaded carbon nanofibers as stable and high-capacity anodes for rechargeable lithium-ion batteries," Applied Materials \& Interfaces, vol. 4, no. 5, Apr. 232012. [Online]. Available: https://doi.org/10.1021/am300333s

[16] Y. L. et al., "Micro-/mesoporous carbon nanofibers embedded with ordered carbon for flexible supercapacitors," Electrochimica Acta, vol. 271, May 1 2018. [Online]. Available: https://doi.org/10.1016/j. electacta.2018.03.199

[17] N. Gallego and D.Edie, "Structure-property relationships for high thermal conductivity carbon fibers," Composites Part A: Applied Science and Manufacturing, vol. 32, no. 8, Aug. 2001. [Online]. Available: https://doi.org/10.1016/S1359-835X(00)00175-5
[18] B. Weidenfeller, M. Höfer, and F. Schilling, "Thermal and electrical properties of magnetite filled polymers," Composites Part A: Applied Science and Manufacturing, vol. 33, no. 8, Aug. 1 2002. [Online]. Available: https://doi.org/10.1016/S1359-835X(02)00085-4

[19] Z. L. et al., "Two-step oxalate approach for the preparation of high performance lini0.5mn1.504 cathode material with high voltage," Journal of Power Sources, vol. 247, Feb. 1 2014. [Online]. Available: https://doi.org/10.1016/j.jpowsour.2013.09.002

[20] E. T. et al. (2003) Young's modulus - tensile and yield strength for common materials. [Ebrary version]. [Online]. [Online]. Available: https://www.engineeringtoolbox.com/young-modulus-d_417.html

[21] M. R. et al., "Investigation of lithium content changes to understand the capacity fading mechanism in lifepo4/graphite battery," Journal of Electroanalytical Chemistry, vol. 853, Nov. 15 2019. [Online]. Available: https://doi.org/10.1016/j.jelechem.2019.113544

[22] M. X. et al., "Improving the electrochemical properties of a siodc/graphite composite anode for high-energy lithium-ion batteries by adding lithium fluoride," Applied Surface Science, vol. 480, Jun. 30 2019. [Online]. Available: https://doi.org/10.1016/j. apsusc.2019.02.207

[23] S. W. et al., "Composite nanofibers through in-situ reduction with abundant active sites as flexible and stable anode for lithium ion batteries," Composites Part B: Engineering, vol. 161, Mar. 152019. [Online]. Available: https://doi.org/10.1016/j.compositesb.2018.12. 039

[24] G. Z. et al., "Zn-mofs derived porous carbon nanofiber for high performance lithium-ion batteries," Surface and Coatings Technology, vol. 359, Feb. 15 2019. [Online]. Available: https: //doi.org/10.1016/j.surfcoat.2018.12.075

[25] Q. L. et al., "High performance porous iron oxide-carbon nanotube nanocomposite as an anode material for lithium-ion batteries," Electrochimica Acta, vol. 212, Sep. 10 2016. [Online]. Available: https://doi.org/10.1016/j.electacta.2016.06.135

[26] J. Z. et al., "Nitrogen-doped carbon nanofibers derived from polyacrylonitrile for use as anode material in sodium-ion batteries," Carbon, vol. 94, Nov. 2015. [Online]. Available: https://doi.org/10. 1016/j.carbon.2015.06.076

[27] L. H. et al., "Free-standing n-doped carbon nanofibers/carbon nanotubes hybrid film for flexible, robust half and full lithium-ion batteries," Chemical Engineering Journal, vol. 334, Feb. 152018. [Online]. Available: https://doi.org/10.1016/j.cej.2017.10.030

[28] S. Yenet al., "Flexible free-standing carbon nanotube films for model lithium-ion batteries," Carbon, vol. 47, no. 13, Nov. 2009. [Online]. Available: https://doi.org/10.1016/j.carbon.2009.06.045

[29] Q. Wu, R. Jiang, and H. Liu, "Carbon layer encapsulated fe3o4areduced graphene oxide lithium battery anodes with long cycle performance," Ceramics International, vol. 46, no. 8, Jun. 1 2020. [Online]. Available: https://doi.org/10.1016/j.ceramint.2020. 02.041

[30] M. Zhang and M. Jia, "High rate capability and long cycle stability fe304-graphene nanocomposite as anode material for lithium ion batteries," Journal of Alloys and Compounds, vol. 551, Feb. 252013. [Online]. Available: https://doi.org/10.1016/j.jallcom.2012.09.115

[31] B. Hirschornet al., "Determination of effective capacitance and film thickness from constant-phase-element parameters," Electrochimica Acta, vol. 55, no. 21, Aug. 30 2010. [Online]. Available: https://doi.org/10.1016/j.electacta.2009.10.065

[32] J. Bisquert, G. Garcia, F. Fabregat, and P. Bueno, "Theoretical models for ac impedance of finite diffusion layers exhibiting low frequency dispersion," Journal of Electroanalytical Chemistry, vol. 475, no. 2, Oct. 14 1999. [Online]. Available: https://doi.org/10.1016/ S0022-0728(99)00346-0

[33] J. Schmidtet al., "Studies on lifepo4 as cathode material using impedance spectroscopy," Journal of Power Sources, vol. 196, no. 12, Jun. 15 2011. [Online]. Available: https://doi.org/10.1016/j. jpowsour.2010.09.121 